\title{
Gearóid Ó Lochlainn: The Gate Theatre’s \\ Other Irish-Speaking Founder
}

\author{
Pádraig Ó Siadhail
}

\section{INTRODUCTION}

Micheál mac Liammóir's name springs to mind immediately when one considers the Gate Theatre's association with the Irish language. However, Gearóid Ó Lochlainn, another of the Gate's four founders and a prominent figure in Dublin's theatre community from the 1920s to the 1960s, was also an Irish speaker. ${ }^{1}$ In their appreciation of Ó Lochlainn after his death in 1970, Hilton Edwards and mac Liammóir acknowledged him as a founding member who served on the Gate's board until 'other activities forced him to retire', and that 'for many years as an actor [he] served as a cornerstone in its company'. They recalled Ó Lochlainn 'as a good friend, courteous, tolerant, and always with dignity and a gentle sagacity'. But they hinted at unknowns in his life story: 'Like many stage people, his off-stage life was private and inviolate, and we knew little of it beyond the fact that he had a charming Danish wife and a family; that he had once been sent to Denmark on some Government mission and

P. Ó Siadhail $(\bowtie)$

Saint Mary's University, Halifax, NS, Canada

e-mail: padraig.osiadhail@smu.ca

(C) The Author(s) 2021

O. Pilný et al. (eds.), Cultural Convergence, https://doi.org/10.1007/978-3-030-57562-5_3 
that, while he was there, he had acted in the Royal Alexander Theatre in Copenhagen.' (1970)

The appreciation lauded Ó Lochlainn but, as we will see, it contained factual errors. More pertinently, in not citing examples of Ó Lochlainn's input to the Gate project in its early years as a founder and one of the original Board directors, it indirectly strengthened the perception that Ó Lochlainn's role was minor and marginal. That may have been a deliberate ploy on mac Liammóir's and Edwards's part as they did not always acknowledge the contribution of the fourth co-founder, 'Toto' Cogley, nor that of Lord Longford, who saved the theatre from bankruptcy in 1930 and remained a key benefactor (Fitz-Simon 218; Cowell 198). Their portrayal of Ó Lochlainn also dovetails with studies of English-language theatre in Ireland, including books about the Gate, which mention Ó Lochlainn only in passing (Clare et al.; Cowell; Hobson; Luke; Pine).

In reality, as mac Liammóir in particular must have known, Ó Lochlainn had published during his lifetime an array of theatre-related writings, primarily in Irish. In multiple series of autobiographical articles, Ó Lochlainn recounted his formative years as an actor in amateur productions in Irish and English in early twentieth-century Dublin, his move to Denmark in 1907 at Arthur Griffith's behest to promote the Irish separatist cause, his marriage and his experiences in the silent film industry in Denmark. Ó Lochlainn's memoirs touch on how British authorities blocked his travel to Ireland in the post-Easter Rising period, his service in Denmark on behalf of Dáil Éireann during the Irish War of Independence and his eventual return home in 1921. Regrettably, Ó Lochlainn never completed his memoirs covering his time as a company member at the Alexandrateatret in Copenhagen and his contributions to Dublin Irish-language and English-language theatre projects, from An Comhar Drámuíochta (1923-1942) to the Pike Theatre Club and An Damer in the 1950s.

Apart from his memoirs, Ó Lochlainn discussed aspects of post1922 Irish-language theatre in newspaper articles and letters in Irish and English. He authored a short book, Ealain na hAmbarclainne [The Art of the Theatre] (1966), based on another series of published articles, exploring the origins of classical drama and the story of theatre in Ireland, thereby permitting further autobiographical reminiscences. Furthermore, many of Ó Lochlainn's Irish-language stage plays and several of his translations were published. Since 1970, a lengthy biographical entry in ainm.ie, An Bunachar Náisiúnta Beathaisnéisí Gaeilge [The National 
Irish-language Biographical Database], and critical discussions by Philip O'Leary in English (2004), and by this author in Irish (Ó Siadhail 1993; Ó Siadhail 2007) of An Comhar Drámuíochta, have detailed Ó Lochlainn's extensive contribution to Irish-language theatre.

As such, Ó Lochlainn is a well-documented individual in Irish-language theatre studies. Accordingly, this chapter aims to fill lacunae in the story of the Gate Theatre and in Irish theatre studies in English by weaving together the following strands: a biographical sketch of Ó Lochlainn including his time in Denmark; a discussion of his role in An Comhar, which the Gate Theatre hosted for four seasons; a summary of what we know about his involvement with the Gate as founder, director and actor; a survey of his plays in Irish including his translations which, in introducing Dublin's Irish-language theatregoers to world drama, complemented the mission of the Gate; his post-Gate career; and an assessment of Ó Lochlainn's theatre career in general terms.

\section{Formative YeArs}

Gearóid Ó Lochlainn - or Gerald Patrick O’Loughlin - was born in Liverpool on 25 April 1884 to Irish-born parents, Elizabeth and Patrick O'Loughlin (Denmark Census 1911). ${ }^{2}$ The family returned to Ireland when Ó Lochlainn was an infant, and he and his Irish-born siblings were raised in Dublin and Tullamore, in King's County (later Offaly). Ó Lochlainn came from an advanced Irish nationalist family. His Wexfordborn father was the 'centre' - the leader - of a Dublin-based 'circle', a unit in the secret revolutionary organization, the Irish Republican Brotherhood (IRB) (Ó Lochlainn 1968e, 24). The 1901 census return for the family in Tullamore lists Patrick and Gerald as clerks for a wholesale drinks company (Census of Ireland 1901). Unlike other family members, both self-identified as Irish-speaking.

Ó Lochlainn moved from Tullamore to Dublin in 1903 and soon began a three-year stint as a clerk in the head office of Conradh na Gaeilge (the Gaelic League). He became acquainted with leading figures in the Irish-language movement, including the League's President, Douglas Hyde, and P.H. Pearse, the editor of its weekly, An Claidheamh Soluis. Through Conradh na Gaeilge, Ó Lochlainn had access to a network of social and cultural activities. He taught Irish at a League branch in Marino, Dublin. He played hurling with a Gaelic Athletic Association club. His family connections and cultural and sporting activities made him 
an ideal recruit for the IRB, which he duly joined (Ó Lochlainn 1968e, 24). But his primary focus after work was theatre.

Theatre in early twentieth-century Dublin was a lively and contested space as Irish nationalists, ranging from physical-force republicans to cultural activists, had competing visions of the role of theatre in Ireland's political evolution and intellectual renewal. As Ó Lochlainn was about to take his first steps on the stage, those visions clashed in 1903 when Dudley Digges and his wife, Máire T. Quinn, parted company with W.B. Yeats, J.M. Synge, and the Irish National Theatre Society in protest against Synge's The Shadow of the Glen (Hogan and Kilroy 1976, 48-49). Later that year, in preparation for Cumann na nGaedheal's Samhain Festival and its Robert Emmet Centenary, Digges assembled a troupe to stage Henry Connell Mangan's Robert Emmet in the Molesworth Hall, Dublin. Billed both as the National Players' Society (NPS) and the Cumann na nGaedheal Theatre Company, the affiliation persisted as NPS became a branch of Cumann na nGaedheal, the precursor of Sinn Féin in 1905 ('Samhain: A Week').

Seán Connolly, a young actor who captained Ó Lochlainn's hurling team, invited him to audition for a minor Irish-speaking role in Robert Emmet (Ó Lochlainn 1962a, 9-10). ${ }^{3}$ Illness delayed Ó Lochlainn's stage debut but he soon appeared in the company's première of Pleusgadh na Bulgoide [The Bursting of the Bubble], Douglas Hyde's satire on Trinity College Dublin, on 3 November 1903. From then until 1907, Ó Lochlainn remained active in NPS, which survived Digges's and Quinn's departure to the United States. The highpoint for Ó Lochlainn was the staging of his play, The Rapparee. NPS presented the one-act tale of romance, murder and revenge set in post-Williamite War Ireland as part of a triple bill in the Queen's Theatre on 18 March 1907 (Hogan and Kilroy 1978, 187-88). Ó Lochlainn later remarked that the play's melodrama matched the Queen's reputation as the natural home for melodramatic fare in Dublin $(1962 c, 4)$. Not only was The Rapparee his first play, it was his only one in English.

From 1905 to 1907, Ó Lochlainn was a member of the cast specially assembled to stage Irish-language plays at An tOireachtas, Conradh na Gaeilge's annual literary and cultural festival held in Dublin. His life changed dramatically in late summer 1907 when Arthur Griffith, the founder of Sinn Féin, approached Ó Lochlainn about a position teaching English in a Berlitz Language School in Aarhus in Denmark. 
According to Ó Lochlainn, Sinn Féin used Berlitz's demand for Englishlanguage teachers as a device to station Sinn Féin representatives abroad to promote the Irish separatist cause. Griffith wanted Ó Lochlainn to replace Michael MacWhite, later a senior figure in the Irish diplomatic service (Ó Lochlainn 1962c, 22). ${ }^{4}$ For Ó Lochlainn, this was a chance to see the world beyond Ireland. He enthusiastically accepted the offer.

\section{DENMARK}

Ó Lochlainn arrived in Aarhus in autumn 1907 and spent two years teaching there before partnering with a German to establish a language school in Odense on the island of Funen. Ó Lochlainn's personal circumstances rapidly changed. On 15 January 1910, he married a young local woman, Rita Ingeborg Bøstrup, in Aarhus (Denmark Marriages 16351916). Born in Mendoza, Argentina in 1890, Ingeborg Bøstrup was one of Ó Lochlainn's early students in Aarhus. Ingeborg joined her husband in Odense, while Seán Ó Duinn, another Sinn Féin placeman, succeeded Ó Lochlainn in Aarhus. But as Ingeborg was unsettled, Ó Lochlainn persuaded Ó Duinn to transfer to Odense, with Ó Lochlainn returning to the Aarhus school in 1911. The following year, Ó Lochlainn successfully applied to teach English in an academy in Copenhagen. He and his wife settled in the Danish capital in September 1912 (Ó Lochlainn 1968a, 9), though he left the academy to teach English privately about a year later (Ó Lochlainn 1968c, 19). ${ }^{5}$

By 1914, Ó Lochlainn was integrated socially and linguistically in Denmark. He did no acting during his early years there but regularly attended plays and was impressed by the high status and vitality of Danish theatre. There is no evidence that he undertook serious propagandistic work for Sinn Féin. Indeed, Ó Lochlainn recalled that there were times, such as for an extended period in 1912, when he and Ó Duinn received no communication from Sinn Féin (1968b, 19). However, using a pseudonym, 'An Lochlannach' [The Viking], which played on his family name and his location, Ó Lochlainn published articles in $A n$ Claidheamh Soluis, An t-Eireannach, the London Conradh na Gaeilge paper and in Sinn Féin (O'Leary 1994, 84 n226). The topics in his An Claidheamh series ranged from commentary on current affairs and international tensions to developments in the world of theatre. In one article, he discussed the challenges of instituting theatre in Iceland, arguing that its experience of launching a permanent company of actors in their own 
dedicated space in Reykjavik provided a model for the Irish-language community (An Lochlannach 1912).

Free to enjoy the Danish capital's theatres, Ó Lochlainn returned to acting in early 1914. Although a competent Danish-speaker by this time, he sounded, he was told, like a Norwegian (Ó Lochlainn 1943, 7). The silent film industry offered a solution. Ó Lochlainn has left a fine description of his early experiences in silent film in Copenhagen, first with the newly-established Dania Biofilm Kompagni, and then in 1915 with its larger rival, Nordisk Film (Ó Lochlainn 1945a-f). ${ }^{6}$ His acting roles were minor but he had steady employment (Ó Lochlainn 1945e, 5). Eventually, at the invitation of Emmanuel Lorentz Larsen, whom he had met filming, Ó Lochlainn joined the company at Copenhagen's Alexandrateatret. His move from film to stage was fortuitous as the World War badly affected Nordisk's activities (Nordisk Film). Though Larsen died in June 1917 (Emmanuel Larsen), Ó Lochlainn spent over three years at the Alexandrateatret (Ó Lochlainn 1943, 1).

Ireland was never far from Ó Lochlainn's thoughts. The British authorities were likely alert to the Irishman in Copenhagen receiving Irish-language and other Irish newspapers. Ó Lochlainn's article in An Claidheamh in 1915 about the role of propaganda in war almost certainly attracted the attention of British wartime censors (An Lochlannach 1915). In turn, the Easter Rising in 1916 startled Ó Lochlainn politically and personally. His brother, Patrick O'Loughlin, had fought in the South Dublin Union during Easter Week and was subsequently interned in Frongoch. Ó Lochlainn's old friend and mentor, Seán Connolly, by 1916 both an Abbey Theatre player and Irish Citizen Army activist, had died in the assault on Dublin Castle on Easter Monday. Unsettled, Ó Lochlainn was keen to return home, even trying to secure employment in advance. By that stage, however, he and Ingeborg had their first child, Rita Emer, born in August 1915 and, with prospects uncertain in Ireland, the family remained in Denmark (Denmark Census 1916).

The British refused to issue Ó Lochlainn a travel permit to return to Ireland in 1917 and 1918 on account of pro-Irish independence articles that he had published in the Copenhagen press (Ó Lochlainn 1966, 51). The convening of the secessionist Dáil Éireann in January 1919 added urgency to the push for international recognition of the Irish Republic. 'Consuls to be sent abroad as soon as practicable probably not practicable now but existing men in other countries might be utilised, Gerald O'Loughlin in Denmark may be thoroughly relied upon', declared Arthur 
Griffith, then incarcerated in Gloucester Prison (Fanning et al., 4). But despite a recommendation to Dáil Éireann in June 1920 about an official appointment (Fanning et al., 72), Ó Lochlainn functioned as its unofficial representative in Denmark for the duration of the Irish War of Independence, while Seán Ó Duinn, still based in Odense, also contributed to the propaganda effort (Art Ó Briain... Ms. 8421/28 and Ms. 8428/9). ${ }^{7}$ Ó Lochlainn's work attracted negative reaction from the Danish authorities. A Dáil Éireann report in March 1921 noted 'that there is interference on the part of the police' (Fanning et al., 123). Another Dáil departmental report stated that Ó Lochlainn 'was recently called before the police authorities and ordered to cease propaganda work for Ireland' (Fanning et al., 185). Writing to his Dáil Éireann contact, Art O’Brien, however, Ó Lochlainn stressed on 3 March 1921 that he was continuing his mission (Art Ó Briain... Ms. 8421/28).

Despite those pressures, 1921 was a joyful year for the Ó Lochlainn family. Ingeborg gave birth to their second child, Finn Georg, in February (Research Foundation). With the advent of the Truce in Ireland in July, British authorities finally approved Ó Lochlainn's passport application and he journeyed home alone that autumn after fourteen years abroad. Clearly, he planned to move back to Ireland permanently and raise his family there. His long relationship with Arthur Griffith, his service on behalf of the Irish cause and his command of Irish resulted in Ó Lochlainn's appointment as Griffith's temporary secretary (Fanning et al., xxvii). However, no sooner was Ó Lochlainn home than the Treaty signing and ratification set the scene for the Split and the Civil War. Loyalty to Griffith may explain Ó Lochlainn's support for the Treaty; in any case, he was not a polemical figure. After Griffiths's sudden death in the early months of the Civil War in August 1922, Ó Lochlainn acted temporarily on behalf of the Provisional Government as 'roving envoy to Berlin and Brussels' (Fanning et al., xxvii). On his return he remained attached to the Department of External Affairs, though he never became a career civil servant. This provided flexibility for him to re-join Irish theatre activities, but without the safety net of a Civil Service pension. Ingeborg and the children, Emer and Finn, only joined Ó Lochlainn in Ireland after the Civil War (Ó Lochlainn 1966, 52). We do not know how Ingeborg viewed the family's move to Ireland or about her subsequent life and experiences in Dublin. 


\section{An Comhar Drámuíochta}

The War of Independence had already disrupted Irish-language theatre and the Civil War compelled Conradh na Gaeilge to cancel An tOireachtas in 1923. But at An tOireachtas's request, Ó Lochlainn assembled remnants of Na hAisteoirí, a Dublin-based troupe established by Piaras Béaslaí ten years previously, to stage a week of plays at the Gaiety Theatre in July 1923. The programme included the first of Ó Lochlainn's eight stage plays in Irish, the one-act Bean an Mbilliunai [The Millionaire's Wife]. He played the role of Ó hArtagáin, a businessman whose sharp practices threaten the livelihood of a small competitor. The latter invades Ó hArtagáin's home, intending to shoot the businessman only for Ó hArtagáin's wife to intercede and for her husband to repent of his heartlessness. The middle-class urban setting was relatively unusual in Irish-language theatre of the time. However, the play was unconvincing in its portrayal of the married couple's relationship and the businessman's volte face. The gunman angle was topical but seems less a comment on the role of the gun in 1923 Ireland than a reflection of the influence of cinema.

The Gaiety week attendance was low; financial losses were high but so too were the energy and enthusiasm to push ahead. Ó Lochlainn became one of the founders of An Comhar Drámuíochta, which launched a season of single-performance Irish-language productions in the Abbey Theatre in November 1923. In still-troubled times, the venture represented a promise of hopeful beginnings. The Free State government soon provided a modest subvention, just as it did to the Abbey, but challenges lay ahead. In the poisoned political post-Civil War atmosphere, suspicion lingered that An Comhar was a favoured government project. There was a paucity of quality original plays. An Comhar possessed no dedicated theatre space while each single-performance production was essentially a dress rehearsal.

Ó Lochlainn was the guiding hand, the jack-of-all-trades, in An Comhar's early seasons. He directed the plays and acted in them too. Productions included, for example, two 1798-themed pieces, An Craipi Og, a translation of the ballad 'The Croppy Boy', transformed by Ó Lochlainn into an operatic number in November 1924, and An Fóghmbar [The Harvest], Ó Lochlainn's reworking of Tomás Ó Ceallaigh's 1907 play, staged in March 1925. A highlight was the première of Liam O'Flaherty's Dorchadas [Darkness] in March 1926, in which Ó Lochlainn 
played the part of Brian, one of two brothers entangled in a deadly Aran Island love triangle.

The dearth of strong original Irish-language plays presented an opportunity to showcase world drama. 'Ní feabhas go comórtas' [Competition leads to excellence], Ó Lochlainn wrote (O'Leary 2004, 392, 638 n91), stressing the importance of staging translations of worthy works, which included plays by Chekhov, Tolstoy and Molière. An Comhar produced three Ó Lochlainn translations in those early seasons. An Cheist Chinneambnach [The Fateful Question], staged in May 1924, was the opening act of Arthur Schnitzler's Anatol, a seven-act German-language play set in Vienna about the musings on life and love by Anatol, a playboy. An Comhar's production, in which Ó Lochlainn played the lead role, let the audience sample Schnitzler's work in Irish a year before the Dublin Drama League presented The Wedding Morning, Anatol's final act ('An Amharclann'; Katz Clarke and Ferrar 29-30). Heircileas, staged in December 1924, was Ó Lochlainn's rendering of the Danish single-act farce Verdens Hercules by Adolph von der Recke and Robert Watt, which, in turn, was an adaptation of Georg Belly's German play Monsieur Herkules. ${ }^{8}$ Set in a hotel, the entrance of visitors leads to mistaken identity and entertaining comedy as the athletic circus performer, Heircileas, is confused with a puny teacher. Deire an Leabhair, staged in October 1926 and Ó Lochlainn's first translation from English, was a thriller in which death arrives via a poison-laden book. The original work, The End of the Book, was an early play by the multi-genre American writer, Henry Myers, who later fell foul of the McCarthy anti-Communist witch-hunt.

\section{Ó Lochlainn and the Gate Theatre}

By 1926, Ó Lochlainn's commitments to An Comhar, on top of his daytime work, took their toll on him. 'I personally was obliged to relinquish the work of production [...] from sheer overstrain', he later wrote (Ó Siadhail 2007, 685). He continued to act with An Comhar but participated in other projects too. As a member of Dublin's theatre community in the mid-1920s, Ó Lochlainn crossed paths with 'Toto' Cogley, the French-born Paris-trained actor, socialist and Irish republican. Despite their contrasting attitudes to the Anglo-Irish Treaty, the pair found common cause in their openness to influences beyond Ireland. In February 1926, they collaborated in Magic, a G.K. Chesterton comedy, staged by the Dublin Drama League which, though an offshoot of the 
Abbey Theatre, anticipated the Gate in staging experimental and international work (Katz Clarke and Ferrar 30). Ó Lochlainn also acted in Seumas McCall's Bealtaine and Eimar O'Duffy's Bricriu's Feast, plays produced by Cogley in Molesworth Hall that June ('Dublin and District').

Contemporary newspaper accounts place Cogley and Ó Lochlainn at events such as the Thalia Cabaret at Daniel Egan's Salon in December 1926 and, in spring 1927, the Cinderella Dance in Clery's Ballroom, a feature of which 'was the cabaret performance in which Madame Bannard Cogley and Mr. Gearoid O Lochlainn introduced Argentine dances and folk songs' ('The Thalia Cabaret'; "“Save the Children" Fund'). They performed at Conradh na Gaeilge's 1927 St. Patrick's Day Concert in Tralee ('Notes on News'; 'Gaelic League Concert'). Ó Lochlainn, who was a fine singer, and Cogley presented 'The Sons of the Sea and Their Shanties' at a fund-raising concert in the Theatre Royal in October 1927 ('Advertisement'). In August 1928, Cogley's radio programme 'Cabaret Pot Pourri' featured Ó Lochlainn ('Dublin Broadcasting'). He also regularly performed at the various iterations of Madame Cogley's Cabaret Club, part of the lively counterculture in Dublin in the first decade of the independent state that, Elaine Sisson argues, prepared the ground for the Gate Theatre (27). Their extended collaboration validates mac Liammóir's description of Ó Lochlainn and Cogley as partners (mac Liammóir 60).

In spring 1928, Ó Lochlainn introduced Hilton Edwards 'to a small group of Dublin people' at 'The Little Theatre' at South William Street where Cogley then hosted her Saturday evening cabarets (W.D.J. 11). Edwards disclosed that he and his fellow actor, mac Liammóir, planned to stage Ibsen's Peer Gynt as part of a new theatre project. Ó Lochlainn and Cogley 'were themselves hoping to start a new theatre, and so the wheels began to turn' (W.D.J. 12). It was in mac Liammóir's and Edwards's interest to cooperate with Cogley and Ó Lochlainn, as the former pair were largely unknown in the Dublin theatre community. As Elaine Sisson notes, Cogley facilitated their 'access to a whole network of actors and writers' (14). In particular, Cogley provided her Cabaret Club members' list - around 400 names - to solicit subscriptions for the new venture (Sisson 13, 25). Similarly, Ó Lochlainn offered strong contacts within, and introductions to, the Dublin theatre community, including Irish speakers who knew little about mac Liammóir before his breakthrough with the new Irish-language theatre in Galway, Taibhdhearc na 
Gaillimhe, in August 1928. 'Gearóid was an actor of distinction and experience', noted mac Liammóir (60). Ó Lochlainn's experience stemmed primarily from his years in Denmark and his knowledge of theatre there (O'Lochlainn [sic] 1921 a and 1921b). His experience in Ireland included success in negotiating An Comhar's subsidy and his acquaintance with senior figures in the Cumann na nGaedheal government. Intriguingly, mac Liammóir remarked: 'Gearóid [...] had, we all thought, a more business-like head than the rest of us.' (60) The basis for that statement is unclear; however, it is worth remembering that Ó Lochlainn and Cogley, both in their early forties in 1928, were significantly older than the twenty-something Edwards and mac Liammóir. Overall, then, it is no surprise that mac Liammóir and Edwards teamed up with Ó Lochlainn and Cogley and that the four were subsequently listed in the circular announcing the Dublin Gate Theatre Studio in September 1928.

In the Gate's inaugural production of Peer Gynt in the Peacock in October 1928, Ó Lochlainn played three roles. He featured regularly during the first season, including in Eugene O'Neill's The Hairy Ape that October and in the English-language première of mac Liammóir's Diarmuid and Gráinne in November. With the second season at the Peacock in spring 1929, Ó Lochlainn appeared in David Sears's Juggernaut in April 1929, in Karel Čapek's R.U.R. in May, in John Galsworthy's The Little Man in June and in the première of Denis Johnston's The Old Lady Says 'No'! in July. His acting credits are a matter of record, but it is difficult to document and assess Ó Lochlainn's other contributions to the Gate project. Mac Liammóir's later occasional comments suggest that Ó Lochlainn was involved in planning, including scouting a permanent home for the Gate (mac Liammóir 82, 88). Ó Lochlainn's use of the plural - 'léiríomar' [we produced], in reference to plays staged in the early seasons - infer his active participation in the Board's discussions and decisions (Ó Lochlainn 1966, 34, 35).

Ó Lochlainn was certainly influential in forging a connection between the Gate and An Comhar Drámuíochta in 1930. An Comhar was in crisis by the late 1920s. The company feared that it might lose its government subvention due to low attendance at the Abbey; moreover, the well-publicized launch of Taibhdhearc na Gaillimhe with the première of mac Liammóir's Diarmuid agus Gráinne accentuated An Comhar's frustrations at its failure to obtain its own space. Accordingly, it transferred its productions to the more modest Peacock and appointed Piaras Béaslaí as director for the 1929-1930 season. That season's week-long 
offerings contained a new one-act piece by Ó Lochlainn, Cótai Móra [Overcoats], in February 1930. Described as 'a jovial, rollicking, farcical comedy of student life in Dublin', Cótai Móra, the text of which appears not to have survived, received uniformly negative reviews, with Frank O'Connor highlighting Ó Lochlainn's fatal attraction to the gunman figure of contemporary cinema ('Stage and Platform'; 'F.O'C.'). Overall, An Comhar's change of location and producer and its longer production runs barely improved matters. Yet there was a ray of hope. Once the Gate moved to its permanent home in the Rotunda complex at the beginning of its third season in February 1930 and it became evident that mac Liammóir did not intend to continue travelling back and forth to Galway, nor to commit himself to An Taibhdhearc on a permanent basis, an opportunity arose. An Comhar rented the Gate for its productions and mac Liammóir agreed to direct its plays.

In effect, An Comhar Drámuíochta was the Gate Theatre's unofficial Irish-language wing from autumn 1930 to spring 1934. Mac Liammóir directed over thirty Irish-language productions at the Gate during that period. Ó Lochlainn acted in plays in two languages there. In November 1930 alone, he was in the cast of T.C. Murray's A Flutter of Wings and in An Geocach Duine Uasal, a translation of Molière's Le Bourgeois Gentilhomme. He relished the opportunity to participate in mac Liammóir's ambitious and artistic Irish-language productions. Likely using his experiences of professional theatre in Copenhagen as a point of comparison and implicitly criticizing the standard of An Comhar productions to date, Ó Lochlainn extolled the quality of the Gate's Irish-language productions:

Sa tréimhse sin sa Gate bhláthaigh an drámaíocht Ghaeilge thar mar bhláthaigh sí riamh roimis ná ó shin. Bhí gach áis againn ann chun slacht agus maise a chur ar na léirithe, agus bhí stiúrthóir agus aisteoir againn i Mac Liammóir nach raibh a mhacasúil le fáil sa tír ach amháin a pháirtí, Hilton Edwards. $(1966,37)$

[In that period at the Gate, Irish-language drama flourished more than it ever flourished before or since. We had access to every technical device to improve and enhance the productions, and, in mac Liammóir, we had a director and actor whose only match in the country was his partner, Hilton Edwards.] 
The Gate Theatre saw drama of another kind as its Board of Directors was transformed in 1931. 'Toto' Cogley departed for England and, as Denis Johnston records, 'severed her active connection with the theatre' (W.D.J. 19). Ó Lochlainn and Lord Glenavy also resigned: Ó Lochlainn acted in the Gate's English-language production of Dmitri Merejkowski's Tzar Paul that March, but that production's programme does not list him as a Gate director. ${ }^{9}$ Meanwhile, Longford and Johnston became directors. Despite mac Liammóir's statement about Ó Lochlainn's business sense, the Gate was in serious financial difficulties by late 1930 through no fault of Ó Lochlainn. An Comhar's contribution for rent would not stave off bankruptcy. Once Longford rescued the Gate project, his appointment to the board was prudent. Johnston was an obvious addition after his The Old Lady Says 'No'! success. But it remains undetermined why Ó Lochlainn resigned in 1931 and what factors explain the Edwards/mac Liammóir statement that 'other activities forced him to retire'.

We know little about Ó Lochlainn's relationship with Edwards but his enthusiasm to continue in mac Liammóir's An Comhar productions (mac Liammóir 1967, 199) and his positive comments about An Comhar under mac Liammóir, dispel suggestions of personal animosity or professional disagreements. Certainly, Ó Lochlainn and mac Liammóir continued to collaborate closely. Mac Liammóir staged Ó Lochlainn's translations of two English-language plays: Greann Hathalaba, his version of The Jest of Hahalaba, Lord Dunsany's modern folktale about human folly, staged in December 1931, and An Sár-Ghadai, Matthew Boulton's playlet about a break-and-entry with a twist in its tail, The Burglar and the Girl, in May 1933. In addition, mac Liammóir produced Ó Lochlainn's first full-length play, $\mathrm{Na}$ Gaduithe [The Thieves] in February 1933 with Ó Lochlainn as Tadhg Ó Tuama, a rural hotelier. The hotel hosts an array of characters, the standard-issue nubile daughters, their prospective suitors, the loyal but much-maligned hotel staff, and - no surprise here - two gun-toting Irish-American bank robbers on the run. The work played successfully for its share of laughs, gasps and romantic sighs, and deservedly earned An Comhar's Craobh Órdha [Gold Branch] for best original play of the 1932-1933 season.

Ó Lochlainn acted in English-language Gate plays until 1933. That year he appeared in mac Liammóir's The Ford of the Hurdles in April and 
in David Sears's Grania of the Ships in September. But he was largely absent after that. In fact, he soon seized the opportunity, one he would likely never receive in the Gate's English-language productions in which mac Liammóir and Edwards regularly filled the lead roles, to play the title role in the Abbey's production of Macbeth in October 1934 (Abbey Theatre Archive).

As inevitable as mac Liammóir's final retreat from Galway was the termination of An Comhar's arrangement with him and the Gate. An Comhar could not call on a wealthy patron, such as Lord Longford, and by early 1934 the Gate rent and production costs became too expensive (Ó Lochlainn 1966, 37). It is unlikely too that mac Liammóir was able or willing to continue his personal commitment indefinitely. The final productions of An Comhar's 1933-1934 season were not in the Gate but back at the Peacock. Mac Liammóir directed those productions, including, in March 1934, Bean an Iasgaire, Ó Lochlainn's translation of T.H. Stafford's The Fisherman's Wife, a one-act tragedy set in a Breton fishing village that in its coastal backdrop, love triangle and sense of impending doom was reminiscent of O'Flaherty's Dorchadas. Ó Lochlainn also acted in mac Liammóir's last An Comhar production, Bean an Ghaiscidhigh, a translation of Martínez Sierra's La Mujer del Héroe, in May 1934 ('The Hero's Wife'). No longer a Gate director, no longer part of the Gate company and no longer working with mac Liammóir in Irishlanguage plays, Ó Lochlainn had tentative connections only with the Gate henceforth. In the absence of early theatre minutes, one can question the full extent of his contribution to the Gate project in its infancy: perhaps an accurate assessment is that while he was less of a cornerstone of the acting company for many years than mac Liammóir and Edwards claimed, he provided street credibility and points of introduction in Dublin for two unknowns at their time of need. Ó Lochlainn was always gracious in acknowledging mac Liammóir's and Edwards's achievements. One can legitimately ask why they were not equally gracious in ensuring that Ó Lochlainn and Cogley were later memorialized as fellow-Gate founders (Fitz-Simon 218).

\section{Ó Lochlainn's Post-Gate Career}

In 1935, Ó Lochlainn undertook a new professional responsibility. ' $[\mathrm{O}]$ rdinarily attached to the Department of External Affairs', it was 
reported, Ó Lochlainn 'is now on loan to the Education Department', where his duties involved promoting Irish-language drama in schools ('Fostering Drama in Schools'). Frequently described as a drama inspector, Ó Lochlainn was active in Gaeltacht areas, including Donegal ('Fostering Drama in Schools'). He also regularly ran workshops with Aisteoirí Ghaoth Dobhair and, when possible, acted with that west Donegal company ('The Gweedore Players') and helped to raise its profile outside Donegal ('From Gweedore'). Ultimately, the drive, if not all the funding, came from within that Gaeltacht community, but the opening of Amharclann Ghaoth Dobhair, the Irish-language theatre in Gaoth Dobhair in 1961, owed no small part to Ó Lochlainn's early support and encouragement.

Back in Dublin, Gate company member Cyril Cusack directed many An Comhar productions in the 1934-1935 and 1935-1936 seasons at the Peacock. An Comhar restructured in 1936, offering performance opportunities for other amateur companies without solving the enduring question of a permanent home. O Lochlainn's commitment to An Comhar continued as a member of its new An Fhoireann Thofa [The Select Cast] and as dramatist. In the late 1930s, he penned three Irish Revolution-themed plays. The one-act An t-Éirighe Amach [The Rising], which premièred in March 1937, recalled Seán O'Casey's Dublin tenement plays in its setting, Dublin's working-class Liberties. As the fighting rages during Easter Week 1916, Pádraig de Clár, a veteran Fenian in failing health, played by Ó Lochlainn in the first production, rues never having struck a blow for Irish independence, though his son, Liam, is out fighting. Soon the roles are reversed as a shell-shocked Liam shelters at home and his father embraces a glorious death. Ó Lochlainn gave voice to neighbours who queried the insurgents' capacity to defeat the British militarily, but, unsurprisingly for the times, he neither introduced the perspective of those whose menfolk were fighting for Britain nor questioned the implications of political violence.

Premièred at the Peacock in January 1938, Na Fearachoin [The Fierce Warriors] was a three-act War of Independence tale of romance and shifting loyalties, as an Anglo-Irish family reassesses its allegiance to Britain. In the final act, the play morphs into a hostage narrative as a British major, played by Ó Lochlainn, awaits with stiff upper-lip his death in retaliation for the execution of IRA Volunteers. Of course, Frank O'Connor had already treated that theme to great effect in his short story, 'Guests of the Nation'. So had Mícheál Ó Siochfhradha in Irish in his play, 
Deire an Chunntais [The End of the Account], premièred at the Gate in April 1931 under the title Dia 'Á Réidhteach [God Save Us].

The unpublished one-act Lá na Paráide [Parade Day], first performed in December 1940, was the most nuanced of Ó Lochlainn's trilogy. Painting 'a picture of an ex-I.R.A. man who has lost everything in the fight for freedom', the play's exploration of the after-effects of war implicitly challenged heroic portrayals of Ireland's recent past ('New Plays in Irish'). As in premières of his other stage works, Ó Lochlainn also featured as an actor, playing the second main character, the Melodeon Man.

An Comhar also produced two Ó Lochlainn translations in the late 1930s, including, in December 1938, Sean-Mhaighread, his version of Old Mag, a one-act Christmas play by Kenneth Sarr, the penname of Kenneth Sheils Reddin. While Ó Lochlainn translated mostly Englishlanguage plays in the 1930s, he also provided an ambitious translation of Henrik Ibsen's En Folkefiende, staged under the title Námbaid don Phobal [An Enemy to the People] at the Peacock in April 1939, with Ó Lochlainn as Dr Stockmann, which earned favourable critical reviews ('Ibsen Play in Irish'; Ar Aghaidh).

In October 1941, Ó Lochlainn acted in two Abbey plays to mark An tOireachtas week, including his final serious play as dramatist, the oneact $A g$ an Ladbrán [At the Junction]. He revisited the theme of Bean an Mhilliunai, while shunning a sentimental ending. Literally and metaphorically, ruthless businessman Pilib Mac Eoin, played by Ó Lochlainn, is at a junction. As he waits for a train and encounters his conscience, 'An Fear Eile' [The Other Man], Mac Eoin must choose which course he will follow. Inevitably, Ó Lochlainn introduces a gun into the action. As the curtain descends, Mac Eoin's fate - suicide - is equally inevitable.

By late 1941, the action off-stage was as significant as that on stage. Ernest Blythe's decision to present Irish-language plays such as $A g$ an Ladbrán reflected not only the Abbey Theatre's rebranding as a bilingual national theatre, but also strategic positioning as Blythe lobbied the government to entrust productions in Irish (and An Comhar's subsidy) to the Abbey. An Comhar soldiered on until 1942 but Tristan is Iseult, a translation of Joseph Bédier and Louis Artus's French-language play, staged by Ó Lochlainn and An Fhoireann Thofa on 24 May at the Abbey, brought the final curtain down on An Comhar as an independent company. The single performance of the play was reminiscent of An Comhar's early productions minus the enthusiasm and optimism of 1923. 
In June 1942, An Comhar's membership, some willingly and others reluctantly, voted in favour of the Abbey absorbing the company.

It is not certain that Ó Lochlainn initially opposed An Comhar's termination as an independent entity. Indeed, he benefitted from the new dispensation, acting in Abbey Irish-language productions in 1943 and 1944. But, ironically, just as some external commentators were hostile to the Abbey's Gaelicization and some Abbey actors were fearful about their prospects as Blythe introduced new bilingual company members (Holloway 89; Ryan 85), many An Comhar veterans, overlooked by the Abbey for parts in Irish-language plays, quickly became disillusioned with the Abbey. Ó Lochlainn, who increasingly resented the Abbey's treatment of his Comhar colleagues, joined other An Comhar stalwarts to launch a new company, Compántas Amharclainne na Gaeilge, which gave its inaugural production at the Gate Theatre on 19 March 1944 when it premièred Séamus de Bhilmot's Prológ don Réim Nua [A Prologue for the New Age] with Ó Lochlainn in the cast. Initially, Compántas was a direct rival to Irish-language productions at the Abbey; in reality, both were in weak positions. In An tOireachtas week in October 1944, both companies staged separate Irish-language productions in which Ó Lochlainn featured. Thirty-five people attended the Abbey; an audience of fourteen people viewed Compántas's play in the Gaiety ('Oireachtas Drama at the Abbey'; “"Black Night”'). Compántas changed tack smartly, pioneering successful Irish-language variety shows in Dublin's main commercial theatres. The Abbey soon shifted focus to occasional short plays staged after its main English-language productions, and to its popular annual Irish-language Christmas pantomime. Ó Lochlainn was in demand by both companies: he featured in HotSeadh, Compántas's first major variety show in May 1945, and in the early Abbey pantomimes, including the inaugural Muireann agus an Prionnsa [Muireann and the Prince] in December 1945, written by Micheál Ó hAodha with additional material by Ó Lochlainn (Sandes 2 ).

Ó Lochlainn continued to move easily across language divides. He was Assistant Director in Aisteoirí Ghaoth Dobhair's visiting productions at the Abbey in September 1946 and appeared in a series of English-language plays at the Gaiety, including Abdication, a piece about Edward VIII by the American writer, H.T. Lowe-Porter, staged by Edwards - mac Liammóir Productions in September 1948. Undoubtedly, Ó Lochlainn welcomed the extra income to augment his Department of Education salary. As much as mac Liammóir described Ó Lochlainn 
as a professional actor $(63,199)$, he was semi-professional in reality. Unsurprisingly, he was keen to see improved working conditions and wages for actors. When the Writers, Actors, Artists and Musicians Association of Ireland (W.A.A.M.A.) became Irish Actors' Equity Association in January 1949, Ó Lochlainn sat on the new committee, becoming Equity's vice-president, a position that he held into the 1960s.

In May 1949, Ó Lochlainn played the role of Shylock in his translation of the trial scene from Shakespeare's The Merchant of Venice at Galway's An Taibhdhearc. Ó Lochlainn subsequently published Radbairc as Drámai Shakespeare (1965), containing his translations from Julius Caesar, Macbeth, The Merchant of Venice and As You Like It. As dramatist, he returned to An Taibhdhearc for the première of his final stage play in April 1950. In An Balbhán Bréige [The Pretend Mute], a Dublin-based painter risks losing the patronage of his rich uncle, played by Ó Lochlainn at the Taibhdhearc, unless he succeeds in conning the visiting uncle that he still employs a mute assistant. Concealment, confusion and comedy ensue before the inevitable happy ending. Back in 1950, the play's treatment of a disability garnered cheap laughs. In fact, the piece proved to be quite popular, with two Dublin productions in the early 1950s, including one by Compántas ('Jubilee Plays of Keating Branch'; 'Two Languages').

Ó Lochlainn participated in two new theatrical ventures in the 1950s. He acted in Carolyn Swift's The Millstone, the initial production of the Swift/Alan Simpson-founded Pike Theatre Players in Dún Laoghaire Town Hall in September 1951 (Carson; Swift 94). When the company moved to the Pike Theatre Club on Herbert Lane, Ó Lochlainn, by then a director of the Pike, featured in the inaugural production, G.K. Chesterton's The Surprise, in September 1953 (Swift 95). Ó Lochlainn also acted in two high-profile Pike productions, as Warder Regan in Brendan Behan's The Quare Fellow in November 1954 and as Father de Leo in Tennessee Williams's The Rose Tattoo in May 1957 (Swift 245). The latter production ran into trouble with Simpson charged, though ultimately not prosecuted, on account of the play's alleged indecent content (Simpson 138-67; Swift 240-58). After Simpson's arrest, the cast assembled to discuss abandoning the run: 'At the meeting, only one member of the cast was understandably against continuing. Gearóid Ó Lochlainn held an unestablished, non-pensionable post in the Department of Education, and would immediately have been dismissed if convicted. Nevertheless, a great believer in trades unionism, he agreed to abide by the majority decision' (Swift 266). ${ }^{10}$ The play completed its run. Ó Lochlainn continued 
to act with the company but the Pike never recovered financially from legal costs arising from the controversy, and 'by 1961 collapsed as an independent theatrical entity' (Pilkington 298).

The Abbey's move to the Queen's Theatre after the fire in July 1951 extinguished lingering hope that the national theatre would stage fulllength plays in Irish. Compántas survived until 1958 but, for financial reasons, scaled back its variety shows and retreated to small venues. By 1954, the Irish-language community began to explore a fresh approach for theatre in Irish. Cumann na Scríbhneoirí, the society of Irishlanguage writers, assembled a committee which included Ó Lochlainn, mac Liammóir, Siobhán McKenna and Cyril Cusack to examine options (Ó Siadhail 1993, 137). However, independent of them, Gael Linn moved quickly to establish An Club Drámaíochta in the Damer Hall in the basement of the Unitarian Church on St Stephen's Green. An Club Drámaíochta opened in November 1955 and An Damer soon became the centre for Irish-language theatre in Dublin. Ó Lochlainn played no leadership role in the project but acted in several productions there, including the June 1958 première of Brendan Behan's An Giall [The Hostage], playing the part of the veteran Monsúr.

Ó Lochlainn's Department of Education appointment likely ended in the late 1950s, at a time when many of his peers had retired. Not surprisingly, his range of activities had diminished by then, although he still appeared in two films, Lies My Father Told Me (1960) and Johnny Nobody (1961), published a new series of memoirs in 1962, and featured in several English-language Abbey plays during the 1960s. His final stage role was in summer 1966 in the inaugural production at the new Abbey Theatre, as one of the Performers in Recall the Years, a backward glance at the Abbey's history. Re-elected as Equity vice-president in 1966, Ó Lochlainn finally stood aside the following year ('Equity's Appeal'; 'Equity Opposes'). He published his theatre book, Ealain na hAmbarclainne, in 1966 and yet another series of memoirs in 1968-1969. The series concluded in January 1969 with a note that Ó Lochlainn's account would resume later (Ó Lochlainn 1969, 23). That was not to be. Ó Lochlainn died in St Mary's Hospital, Phoenix Park, on 21 July 1970.

\section{An Actor in Search of an Audience}

Gearóid Ó Lochlainn's Gate years, 1928-1934, were a small part of his lengthy, distinguished career in Irish theatre. Ó Lochlainn was no mere 
'drama enthusiast' (Fitz-Simon 52): he was an internationally-experienced man of the theatre and a professional actor in all but name. Nor was he a mere 'Irish language enthusiast' (Sisson $12 \mathrm{n} 5$ ): for the multilingual Ó Lochlainn, Irish was his language of preference. His life story demonstrated an openness to the outside world and a willingness to learn from others abroad, not least from those striving to maintain their own languages and cultures. Unlike his An Comhar colleague, Piaras Béaslaí, who refused to acknowledge his Merseyside origins, or Micheál mac Liammóir, whose lifelong professional theatrical role was as pure laine Gael, Ó Lochlainn did not conceal his birth in Britain. His wife was Danish. His children were Danish-born. The cosmopolitan Ó Lochlainn was comfortable in his Irishness, while happy to embrace the best of other cultures.

Ó Lochlainn filled multiple roles during his theatrical career, from actor to actors' union representative. Those as dramatist and actor are most notable. It is no coincidence that his plays from the 1920s onwards were in Irish, as he sought to provide well-constructed dramatic fare for the Irish-language theatre community. Ó Lochlainn grew to become a competent author of popular drama, whose knowledge of stagecraft helped him to set the scene in his plays, to create distinctive characters and to move those characters on and off the stage. Mixing lively dialogue, action and, not infrequently, music and song (which he usually wrote) and, as we have seen, the gun and gunman from cinema, he fashioned stage works that entertained without touching his audience deeply or challenging them intellectually. Ó Lochlainn acknowledged his plays' modest artistic merit $(1951,22)$ but, in their time, they served their primary goal of cultivating an audience for theatre in Irish.

Micheál Ó hAodha's description of Ó Lochlainn as 'an actor in search of an audience' (69) captures Ó Lochlainn's first and most enduring theatrical passion. While mac Liammóir praised Ó Lochlainn's ability as an actor (60), Cyril Cusack hinted at his limitations. ${ }^{11}$ 'Maireann an t-aisteoir míle beatha' [The actor lives a thousand lives], declared Ó Lochlainn in a poem $(1959,15)$. His thousand lives encompassed roles in silent films, on Danish stage, and in English and Irish. His acting experiences in Irish and English differed significantly. In the former, he was frequently the leading man; in the latter, he was usually a supporting player. But his acting in Ireland, in the National Players' Society's productions in two languages, 
in Irish-language ventures from An Comhar Drámuíochta to An Damer, and in English-language theatre from the Gate to the Pike and the Abbey highlighted not only Ó Lochlainn's personal accomplishments but his vision for Irish theatre in which actors and dramatists would find an audience for high-quality work whether in Irish or English. For Ó Lochlainn, that meant that 'Amharclann Ghaeilge' - an Irish-language theatre - was essential in Dublin $(1951,23)$. That prospect is more remote today than in the 1920s when he and his colleagues launched An Comhar, or in the 1930s when mac Liammóir directed its productions at the Gate, or even in the early 1940s when the Abbey could claim, with some legitimacy, to be Ireland's national theatre.

\section{Notes}

1. A signed photo of Gearóid Ó Lochlainn has been digitized by the National Library of Ireland and may be viewed at http://catalogue.nli. ie/Record/vtls000283525.

2. Although Ó Lochlainn's birth certificate has not been located, Danish marriage and census records confirm his place of birth and his date of birth. Except where other sources are cited, information about Ó Lochlainn's life is drawn from his ainm.ie entry.

3. In his memoirs, Ó Lochlainn refers to Connolly as Seán Ó Conghaile.

4. Ó Lochlainn used the Irish version of MacWhite's name, Mícheál Mac Faoite.

5. Muiris Ó Droighneáin claims that Ó Lochlainn studied at 'Ollsgoil Chopenhagen' [the University of Copenhagen] (219). However, Ó Lochlainn makes no mention of such studies in his memoirs.

6. Unfortunately, Ó Lochlainn did not name the silent films in which he appeared.

7. An interesting feature of Ó Lochlainn's and Ó Duinn respective letters to their Dáil Éireann contact, Art O'Brien, is that Ó Lochlainn always wrote in Irish while Ó Duinn corresponded in English.

8. Ó Lochlainn's published translation of Heircileas does not provide the names of the Danish play and its authors or details about the play's German provenance.

9. Email correspondence from Ondřej Pilný, Charles University, Prague, to the author, 15 July 2019.

10. In his account of this incident, Alan Simpson - unlike Carolyn Swift - did not name Ó Lochlainn, 'who held an unestablished, non-pensionable post as a Cultural Adviser to a State body, and who was liable to dismissal at a week's notice $[\ldots]$ This actor bravely agreed to abide by the majority 
decision, even though he was very worried about the possible reaction of his superiors.' (155)

11. Cyril Cusack commented that Ó Lochlainn was perhaps not the world's best actor but was fully committed to the cause of Irish-language theatre ('[...] b’fhéidir nárbh é an t-aisteoir ab fhearr ar domhan é, ach bhí sé chomh tugtha sin do chúis na hamharclainne Gaeilge') (Cusack 6).

\section{Works Cited}

\section{WORKS BY GEARÓID Ó LOCHLAINN}

An Lochlannach. 1912. 'Aisteoireacht 'san Íslinn'. An Claidheamb Soluis, 5 Deireadh Fómhair, 4-5.

An Lochlannach. 1915. 'Bréaga an Chogaidh'. An Claidheamh Soluis, 28 Lúnasa, 2.

Heircileas. n.d. Trans. G. Ó Lochlainn. Áth Cliath: An Comhar.

Ibsen, Henrik. 1947. Námbaid don Phobal [En Folkefiende]. Trans. Gearóid Ó Lochlainn. Baile Átha Cliath: Oifig an tSoláthair.

O'Lochlainn [sic], Gearóid. 1921a. 'The Danish Theatre'. Banba 1.5 (September): 355-60.

O'Lochlainn [sic], Gearóid. 1921b. 'The Danish Theatre'. Banba 2.1 (November): 16-21.

Ó Lochlainn, Gearóid. 1923. Bean an Mhilliúnai. Baile Átha Cliath: Clódhanna Gaedhealacha.

Ó Lochlainn, Gearóid. 1935. Na Gaduithe. Baile Átha Cliath: Oifig Díolta Foillseacháin Rialtais.

Ó Lochlainn, Gearóid. 1943. 'Nodlaig Aisteora sa Danmhairg'. Combar 2.8 (Nollaig): 1,7 .

Ó Lochlainn, Gearóid. 1944. Ant-Éirighe Amach. Baile Átha Cliath: Oifig an tSoláthair.

Ó Lochlainn, Gearóid. 1945a. ‘Aisteoir Fáin’. Combar 4.3 (Márta): 3.

Ó Lochlainn, Gearóid. 1945b. 'Aisteoir Fáin - II'. Combar 4.4 (Aibreán): 3, 9.

Ó Lochlainn, Gearóid. 1945c. 'Aisteoir Fáin - III'. Combar 4.5 (Bealtaine): 2.

Ó Lochlainn, Gearóid. 1945d. 'Aisteoir Fáin - IV'. Combar 4.6 (Meitheamh): 8.

Ó Lochlainn, Gearóid. 1945e. 'Aisteoir Fáin - V'. Combar 4.7 (Iúil): 5.

Ó Lochlainn, Gearóid. 1945f. ‘Aisteoir Fáin - VI’. Combar 4.8 (Lúnasa): 7-8.

Ó Lochlainn, Gearóid. 1946a. Ag an Ladbrán. Baile Átha Cliath: Oifig an tSoláthair.

Ó Lochlainn, Gearóid. 1946b. Na Fearachoin. Baile Átha Cliath: Oifig an tSoláthair.

Ó Lochlainn, Gearóid. 1951. 'Freagra ar Thomás Mac Anna: Bhíodh Caighdeán Gairmiúil ag an Chomhar Drámaíochta'. Combar 10.5 (Bealtaine): 9-10, 19-23.

Ó Lochlainn, Gearóid. 1954. An Balbhan Bréige. Baile Átha Cliath: Oifig an tSoláthair. 
Ó Lochlainn, Gearóid. 1959. 'An tAisteoir'. Feasta 12.4 (Iúil): 15.

Ó Lochlainn, Gearóid. 1962a. 'Ag Amharc Siar Dom'. Feasta 14.11 (Feabhra): 9-10, 25-26.

Ó Lochlainn, Gearóid. 1962b. 'Ag Amharc Siar Dom - II'. Feasta 14.12 (Márta): 4-6, 25.

Ó Lochlainn, Gearóid. 1962c. 'Ag Amharc Siar Dom - III'. Feasta 15.1 (Aibreán): 4-6, 21-22.

Ó Lochlainn, Gearóid. 1962d. 'Ag Amharc Siar Dom - IV'. Feasta 15.2 (Bealtaine): 4-6.

Ó Lochlainn, Gearóid. 1966. Ealaín na hAmbarclainne. Baile Átha Cliath: Clódhanna Teoranta.

Ó Lochlainn, Gearóid. 1968a. 'I dTír na nDanar Dom'. Feasta 21.5 (Lúnasa): 5-9.

Ó Lochlainn, Gearóid. 1968b. 'I dTír na nDanar Dom'. Feasta 21.6 (Meán Fómhair): 17-19.

Ó Lochlainn, Gearóid. 1968c. 'I dTír na nDanar Dom'. Feasta 21.7 (Deireadh Fómhair): 18-20.

Ó Lochlainn, Gearóid. 1968d. 'I dTír na nDanar Dom'. Feasta 21.8 (Samhain): 17-21.

Ó Lochlainn, Gearóid. 1968e. 'I dTír na nDanar Dom'. Feasta 21.9 (Nollaig): 23-25.

Ó Lochlainn, Gearóid. 1969. 'I dTír na nDanar Dom'. Feasta 21.10 (Eanáir): 21-23.

Shakespeare, William. 1965. Radhairc as Drámai Shakespeare. Trans. Gearóid Ó Lochlainn. Baile Átha Cliath: Oifig an tSoláthair.

\section{OTHer SOURces}

Abbey Theatre Archive. https://www.abbeytheatre.ie/archives/person_detail/ 11748/. Accessed 12 September 2019.

'Advertisement'. 1927. Irish Independent, 21 October, 6.

Ainm.ie. 'Ó Lochlainn, Gearóid (1884-1970)'. https://www.ainm.ie/Bio.aspx? ID $=345$. Accessed 12 September 2019.

'An Amharclann'. 1924. Freeman's Journal, 6 May, 6.

Ar Aghaidh. 1939. 'Gaelic Drama: An Comhar Dramuiochta'. Leader, 26 August, 84.

Art Ó Briain Papers. National Library of Ireland. Ms. 8421/28.

Art Ó Briain Papers. National Library of Ireland. Ms. 8428/9.

“"Black Night” for Drama in Irish'. 1944. Irish Press, 27 October, 3.

Carson, Niall. 1951. 'Theatre. New Group Has Its Own Playwright'. Irish Press, 27 August, 4. 
Census of Ireland. 1901. http://www.census.nationalarchives.ie/pages/1901/ King_s_Co_/Tullamore_Urban/Church_Street/1471936/ and http://www. census.nationalarchives.ie/reels/nai000956221/. Accessed 12 September 2019.

Clare, David, Des Lally, and Patrick Lonergan, eds. 2018. The Gate Theatre, Dublin. Inspiration and Craft. Oxford and New York: Peter Lang/Carysfort Press.

Cowell, John. 1988. No Profit but the Name: The Longfords and the Gate Theatre. Dublin: The O'Brien Press.

Cusack, Cyril. 1990. 'Agallamh na Míosa. Marie Ní Chonchubhair ag caint le Cyril Cusack, Aisteoir'. Combar, 49.11 (Samhain): 5-8, 10-12.

Denmark Census. 1911. Database with images. FamilySearch. https://familysearch. org/ark:/61903/1:1:Q2W4-HJ13. 8 May 2018. Gearvid [sic] O'Lochlainn, Odense, Danmark; from 1911 Denmark Census database. MyHeritage. https:// www.myheritage.com. 2016; citing Odense, Danmark; Rigsarkivet, København (The Danish National Archives), Copenhagen. FHL microfilm 100,950,350. Accessed 12 September 2019.

Denmark Census. 1916. Database with images. FamilySearch. https://familysea rch.org/ark:/61903/1:1:Q2CZ-G79V. 12 July 2017. Rita Emer O'Lochlainn in entry for Gerald Patrick O'Lochlainn, Copenhagen, Denmark; from 1916 Denmark Census database and images. MyHeritage. https://www.myheritage. com. 2016, film 08004; citing household 1012779, Rigsarkivet, København (The Danish National Archives), Copenhagen; FHL microfilm 103,920,392. Accessed 12 September 2019.

Denmark Marriages, 1635-1916. Database. FamilySearch. https://familysea rch.org/ark:/61903/1:1:FVT7-99N. 11 February 2018. Gerald Patrick O’Loughlin and Rita Ingeborg Bøstrup, 15 Jan 1910; citing C Raahuset, Århus, Århus, Denmark, reference b4 p 209 \#4; FHL microfilm 408,095. Accessed 12 September 2019.

'Dublin and District'. 1926. Irish Independent, 10 June, 8.

'Dublin Broadcasting Programmes for the Week'. 1928. Sunday Independent, 19 August, 2.

Edwards, Hilton, and Micheál mac Liammóir. 1970. 'Gearoid O Lochlainn. An Appreciation'. Irish Times, 24 July, 6.

Emmanuel Larsen. https://www.gravsted.dk/person.php?navn=emmanuellarsen. Accessed 12 September 2019.

'Equity Opposes Plan for Master Aerials'. 1967. Irish Independent, 20 March, 3.

'Equity's Appeal to Managers'. 1966. Irish Press, 4 April, 4.

F.O'C. [Frank O'Connor]. 1930. 'Abbey-cum-Boccaccio'. Irish Statesman, 22 February, 498. 
Fanning, Ronan, Michael Kennedy, Dermot Keogh, and Eunan O’Halpin, eds. 1998. Documents on Irish Foreign Policy. Volume 1. 1919-1922. Dublin: Royal Irish Academy.

Fitz-Simon, Christopher. 1994. The Boys: A Double Biography. London: Nick Hern Books.

'Fostering Drama in Schools'. 1935. Irish Press, 13 September, 1.

'From Gweedore to Dublin. The Story of a Success'. 1940. Derry People, 27 July, 3.

'Gaelic League Concert'. 1927. Kerry News, 18 March, 3.

Hobson, Bulmer, ed. 1934. The Gate Theatre Dublin. Dublin: The Gate Theatre.

Hogan, Robert, and James Kilroy. 1976. Laying the Foundations 1902-1904. Dublin and Atlantic Highlands, NJ: The Dolmen Press and Humanities Press.

Hogan, Robert, and James Kilroy. 1978. The Abbey Theatre: The Years of Synge 19051909. Dublin and Atlantic Highlands, NJ: The Dolmen Press and Humanities Press.

Hogan, Robert, and Richard Burnham. 1992. The Years of O'Casey, 1921-1926. A Documentary History. Newark, NJ: University of Delaware Press/Gerrards Cross: Colin Smythe.

Holloway, Joseph. 1970. Joseph Holloway's Irish Theatre. Eds Robert Hogan and Michael J. O’Neill. Vol. 3. Dixon, CA: Proscenium Press.

'Ibsen Play in Irish'. 1939. Irish Times, 26 April, 8.

'Jubilee Plays of Keating Branch'. 1951. Irish Independent, 12 May, 7.

Katz Clarke, Brenna, and Harold Ferrar. 1979. The Dublin Drama League 19181941. Dublin and Atlantic Highlands, NJ: The Dolmen Press and Humanities Press.

Luke, Peter, ed. 1978. Enter Certain Players. Edwards-Mac Liammoir and the Gate. Dublin: The Dolmen Press.

mac Liammóir, Micheál. 1967. All for Hecuba: An Irish Theatrical Autobiography. Boston: Branden Press.

'New Plays in Irish'. 1940. Irish Press, 11 December, 3.

Nordisk Film. https://www.nordiskfilm.com/about. Accessed 12 September 2019.

'Notes on News'. 1927. Kerry News, 14 March, 2.

Ó Droighneáin, Muiris. 1936. Taighde i gcombair Stair Litridheachta na NuaGhaedhilge ó 1882 anuas. Baile Átha Cliath: Oifig Díolta Foillseacháin Rialtais.

Ó hAodha, Micheál. 1990. The Importance of Being Micheál. A Portrait of MacLiammóir. Dingle, Co. Kerry: Brandon.

O'Leary, Philip. 1994. The Prose Literature of the Gaelic Revival: Ideology and Innovation. University Park, PA: The Pennsylvania State University Press.

O'Leary, Philip. 2004. Gaelic Prose in the Irish Free State 1922-1939. University Park, PA: The Pennsylvania State University Press. 
Ó Siadhail, Pádraig. 1993. Stair Dhrámaíocht na Gaeilge 1900-1970. Indreabhán: Cló Iar-Chonnachta.

Ó Siadhail, Pádraig. 2007. An Béaslaíoch. Beatha agus Saothar Phiarais Béaslaí (1881-1965). Baile Átha Cliath: Coiscéim.

'Oireachtas Drama at the Abbey'. 1944. Irish Press, 23 October, 3.

Pilkington, Lionel. 2016. 'The Little Theatres of the 1950s'. In The Oxford Handbook of Modern Irish Theatre. Eds Nicholas Grene and Chris Morash, 292-98. Oxford: Oxford University Press.

Pine, Richard, and Richard Allen Cave. 1984. The Dublin Gate Theatre 1928-1978. Cambridge and Teaneck, NJ: Chadwyck-Healey.

Research Foundation for Music in Ireland. https://www.musicresearch.ie/?q=olo chlainncollection. Accessed 12 September 2019.

Ryan, Phyllis. 1996. The Company I Kept. Dublin: Town House \& Country House.

'Samhain: A Week of Irish Plays. The Plots of the New Plays'. 1905. Irish Independent, 30 October, 7.

Sandes, J.P. 1945. 'Dublin Will Have a Wide Choice in Christmas Shows'. Sunday Independent, 9 December, 2.

"“Save the Children" Fund'. 1927. Evening Herald, 11 March, 5.

Simpson, Alan. 1962. Beckett and Behan and a Theatre in Dublin. London: Routledge and Kegan Paul.

Sisson, Elaine. 2018. 'Experiment and The Free State: Mrs Cogley's Cabaret and the Founding of the Gate Theatre 1924-1930'. In The Gate Theatre, Dublin: Inspiration and Craft. Eds David Clare, Des Lally, and Patrick Lonergan, 11-27. Oxford and New York: Peter Lang/Carysfort Press.

'Stage and Platform. The Gaelic Players'. 1930. Sunday Independent, 16 February, 2. Swift, Carolyn. 1985. Stage by Stage. Swords, Co. Dublin: Poolbeg.

'The Gweedore Players. Splendid Entertainment'. 1938. Strabane Chronicle, 3 September, 1 .

'The Hero's Wife'. 1934. Irish Press, 9 May, 9.

'The Thalia Cabaret'. 1926. Evening Herald, 13 December, 3.

'Two Languages Laughed together for Compantas'. 1955. Irish Press, 15 March, 7.

W.D.J. 1934. 'The Making of the Theatre'. In The Gate Theatre Dublin. Ed. Bulmer Hobson, 11-20. Dublin: The Gate Theatre. 
Open Access This chapter is licensed under the terms of the Creative Commons Attribution 4.0 International License (http://creativecommons.org/licenses/ by $/ 4.0 /$ ), which permits use, sharing, adaptation, distribution and reproduction in any medium or format, as long as you give appropriate credit to the original author(s) and the source, provide a link to the Creative Commons license and indicate if changes were made.

The images or other third party material in this chapter are included in the chapter's Creative Commons license, unless indicated otherwise in a credit line to the material. If material is not included in the chapter's Creative Commons license and your intended use is not permitted by statutory regulation or exceeds the permitted use, you will need to obtain permission directly from the copyright holder.

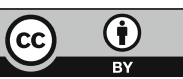

